\title{
Evidence from the Lebanon Global School-based Student Health Survey on midwakh tobacco smoking in school students: a harbinger of the next global tobacco pandemic?
}

\author{
Rima Afifi, ${ }^{1,2}$ Monisa Saravanan, ${ }^{1}$ Noura El Salibi, ${ }^{3}$ Rima Nakkash, ${ }^{2}$ Alossar Rady, ${ }^{4}$ Scott Sherman ${ }^{5}$ and Lilian Ghandour ${ }^{3}$
}

${ }^{1}$ Department of Community and Behavioral Health, College of Public Health, University of Iowa, Iowa City, Iowa, United States of America. ${ }^{2}$ Department of Health Promotion and Community Health, Faculty of Health Sciences, American University of Beirut, Beirut, Lebanon. ${ }^{3}$ Department of Epidemiology and Population Health, Faculty of Health Sciences, American University of Beirut, Beirut, Lebanon. ${ }^{4}$ World Health Organization Country Office, Beirut, Lebanon. ${ }^{5}$ Department of Population Health, Langone Health, New York University, New York, United States of America. (Correspondence to: Lilian Ghandour: lgo1@aub.edu.lb).

\begin{abstract}
Background: Cigarette smoking is the most common form of tobacco consumption but other methods have grown in popularity. In the United Arab Emirates and other Gulf countries, smoking dokha, a form of tobacco mixed with herbs and spices in a midwakh pipe, is common.

Aims: The aim of this study was to determine the prevalence of midwakh use in school students in Lebanon and factors associated with its use.

Methods: Data on tobacco use from the Lebanon Global School-based Student Health Survey (GSHS), 2017 were analysed, including current midwakh use (defined as midwakh use at least once in the 30 days before the survey). The survey includes school students in grades 7-12 (12-18 years). Current midwakh use was analysed according to sociodemographic and tobacco-related variables using bivariate and logistic regression analyses.

Results: Of the 5590 students included in the analysis, $4.6 \%$ were current midwakh users. Current midwakh use was significantly more prevalent in students 13 years and older and in male students $(\mathrm{P}<0.01)$. Current use was also statistically significantly more prevalent in students in public than private schools. Current cigarette smoking (OR $=15.22 ; 95 \% \mathrm{CI}$ : 11.08-20.90), ever use of a waterpipe ( $\mathrm{OR}=9.61 ; 95 \% \mathrm{CI}$ : 6.66-13.86) and parental smoking (OR $=1.56$; 95\% CI: 1.05-2.31) were also significantly associated with current midwakh use.

Conclusion: Although midwakh use is low in Lebanon, the patterns of association of midwakh use are similar to those of cigarette and waterpipe smoking in young people. Further research is needed to understand the context of midwakh use and prevent it from spreading.
\end{abstract}

Keywords: tobacco use, smoking, midwakh pipe, students, Lebanon

Citation: Afifi R; Saravanan M; El Salibi N; Nakkash R; Rady A; Sherman S et al. Evidence from the Lebanon Global School-based Student Health Survey on midwakh tobacco smoking in school students: a harbinger of the next global tobacco pandemic? East Mediterr Health J. 2020;26(1):116-121. https://doi.org/10.26719/2020.26.1.116

Received: 12/04/19; accepted: 25/07/19

Copyright (C) World Health Organization (WHO) 2020. Open Access. Some rights reserved. This work is available under the CC BY-NC-SA 3.0 IGO license (https://creativecommons.org/licenses/by-nc-sa/3.o/igo).

\section{Introduction}

Although tobacco use globally is decreasing, it is on the rise in Africa and the Eastern Mediterranean Region. It kills 6 million people every year worldwide, and this number is predicted to increase to 8 million each year by $2030(1-3)$. Cigarettes are the most common type of tobacco consumed globally; however, other types of consumption - often called alternative tobacco products - have increased in popularity, such as waterpipe smoking (1).

In the Arab world, consumption of alternative tobacco products, including waterpipe smoking, has increased rapidly, particularly among young people (4). Dokha - an Arabic word meaning dizziness - is another alternative tobacco product that is gaining popularity in the Arab world (5). Dokha is a form of tobacco leaves mixed with dried fruits, herbs, bark, spices, and dried flowers, which is smoked using a narrow pipe called a midwakh (5). About $0.5 \mathrm{~g}$ of dokha is placed in the midwakh, one or two deep inhalations are taken to burn the dokha, and this is done an average of 12 times a day (6). Dokha is available in different strengths ranging from mild to strong (4).

Little research has been done on dokha smoking using a midwakh, with most published reports coming from the United Arab Emirates and anecdotal reports coming from elsewhere in the Gulf region. Emerging evidence suggests that dokha is not a safe alternative to traditional cigarette smoking. Acute effects of smoking dokha include increased systolic blood pressure, heart rate and respiratory rate $(4,5,7,8)$. Chronic use of dokha can result in excessive stimulation of the sympathetic nervous system leading to increases in heart rate and cardiac output which can damage blood vessels (8). The nicotine in dokha can also cause constriction of the airways resulting in shortness of breath or tachypnoea (8). Median carbon monoxide and salivary cotinine levels in midwakh smokers were similar to those of cigarette smokers and higher than those of non-smokers (9). 
The negative health outcomes of dokha smoking are particularly concerning given its increasing prevalence and popularity, especially among young people $(6,10)$. Dokha is preferred to cigarettes and other alternative tobacco products such as waterpipe (hookah) because it: produces a strong light-headed sensation, satisfies nicotine craving more quickly, produces less secondhand smoke, has no smell, does not stain the lips, is less bulky than a waterpipe and even a cigarette packet, and is relatively cheap $(6,10)$. About $89 \%$ of the population of the United Arab Emirates are non-nationals, including nationals of the United States of America (USA) and other high-income countries. A study of ninth-grade male expatriate school students, found that $15 \%$ had used a midwakh at least once in the previous 30 days, with an average of 25 days of use, and 2-3times a day (11). A more recent study found that the prevalence rates of ever and current smoking with a midwakh in expatriate school students (North American, Australian and/or European) in the United Arab Emirates were not significantly different from those of Emirati students (12). Therefore, while midwakh use has been most popular in the United Arab Emirates and other Gulf countries, this alternative tobacco product threatens to spread within and beyond the Arab world $(5,12,13)$.

The objective of our study was to assess the prevalence of midwakh smoking in middle- and high-school students in Lebanon, and to explore sex and age differences and associations with smoking other tobacco products.

\section{Methods}

The Global School-based Student Health Survey (GSHS) is a surveillance tool developed by the World Health Organization (WHO) and the Centers for Disease Control and Prevention $(C D C)$, and conducted in collaboration with ministries of health and education (14). It is a schoolbased survey conducted mainly among a representative sample of adolescents in in grades 7 through 12 (about ages $13-18$ years).

\section{Sampling procedures}

Centers for Disease Control and Prevention determined the sample size and sampling procedures using a sampling frame provided by the Ministry of Education and Higher Education in Lebanon. In order to get representative data with a $5 \%$ error, the minimum sample size was calculated to be 1534 students. A two-stage cluster sample design was used to select a representative sample of students in grades 7-12 in schools in Lebanon. The first stage was a systematic sampling of schools with probability proportional to school enrolment size. A total of 64 schools were selected. The second stage was equal probability sampling of classrooms: all classes with most of the students in grades 7-12 were included in the sampling frame. The list of selected schools and classrooms was shared with the Ministry of Education and Higher Education for data collection. All students in the sampled classrooms were eligible to participate in the survey. Out of the 64 selected schools, 56 agreed to participate, giving a school response rate of $88 \%$. Of the 6152 students selected, 5717 completed the survey, giving a student response rate of $93 \%$. Hence, the overall response rate was $82 \%$ $(0.88 \times 0.93 \times 100)$. Of the completed surveys, 5708 were usable after data cleaning.

\section{GSHS questionnaire and main measures}

The 2017 GSHS conducted in Lebanon used an 88-item questionnaire: 54 core questions and 34 core-expanded or Lebanon-specific questions. The questionnaire was developed in English and Arabic and students were allowed to choose which language they wanted to complete it in.

For the purpose of our analysis, we included the following measures:

Sociodemographic data: age ( $\leq 12$ years, $13-15$ years, 16-17 years and $\geq 18$ years), sex (male/female), school grade (7-12) and type of school (private/public).

Tobacco use: Our main outcome was current midwakh use (yes/no), which was assessed by the following question: "During the past 30 days, on how many days did you smoke a midwakh or smoking pipe?" We categorized a response of 0 days as non-current midwakh use and all other responses as current midwakh use. Only 5590 students answered this question. Further analyses (results available on request) showed that the students who did not respond to the midwakh question did not differ significantly from those who did answer this question in terms of sociodemographic and other tobacco use variables. Therefore, the data are missing at random and less likely to introduce bias and affect our results. Other questions on tobacco use included: age at which students first tried cigarettes; waterpipe use (ever/ never); number of days they had smoked cigarettes in the 30 days before the survey; exposure to second-hand smoke in the 7 days before the survey, including any form of smoked tobacco use by parents or guardians.

\section{Data collection}

The survey is self-administered and students answered it in school during school hours. Students were informed about the survey and its content, their rights and the voluntary nature of participation. Students recorded their answers on an answer sheet that could be scanned by computer. Survey procedures were designed to protect the students' privacy and allow for anonymous and voluntary participation.

\section{Data analysis}

Epi Info and Stata software was used for data analyses. To ensure the data were representative of all students in grades 7-12, a weighting factor was applied to each student record to adjust for non-response and for the varying probabilities of selection. Univariate and bivariate analyses were performed, and also adjusted logistic regression analyses to control for age, sex and school type (these three variables were statistically significantly associated with midwakh use in the bivariate analysis). Data are reported as frequencies and odds ratios (ORs) and 95\% confidence intervals ( $95 \%$ CIs). 


\section{Results}

A total of 5590 students were included in the analysis. Of these students, 3309 (59.2\%) were female, 3597 (64.3\%) were in public schools, 3341 (59.8\%) were aged 15 years or younger and $2326(41.6 \%)$ were in grades 7 or 8 (Table 1).

Overall, 275 (4.6\%) students were current midwakh users - had used a midwakh at least once in the 30 days before the survey. Current midwakh use was significantly more prevalent in students 13 years and older and in male students $(P<0.01)$ (Table 1$)$. Current use was also statistically significantly more prevalent in students in public than private schools (Table 1).

Current midwakh use was significantly associated with current cigarette smoking $(\mathrm{OR}=15.22$; 95\% CI: 11.08 20.90, $P<0.001)$ and starting cigarette smoking younger than 14 years of age among cigarette smokers $(\mathrm{OR}=2.34$; 95\% CI: 1.49-3.68, $P=0.001$ ), after adjusting for age, sex and school type. Midwakh use was also significantly associated with ever smoking a waterpipe $(\mathrm{OR}=9.61$; 95\% CI: 6.66-13.86, $P<0.001)$ and parental smoking $(\mathrm{OR}=1.56 ; 95 \% \mathrm{CI}: 1.05-2.31, \mathrm{P}=0.029)$ after controlling for age, sex and school type (Table 2). Exposure to secondhand smoke was not significantly associated with current midwakh use $(P=0.128)$.

\section{Discussion}

Our study provides prevalence rates of midwakh use outside the United Arab Emirates and other Gulf areas, where it has been mostly confined. We also explored sex and age differences, and associations with smoking other tobacco products. Overall, $275(4.6 \%)$ of students in grades 7-12 currently smoked midwakh; current use ranged between $2.4 \%$ in students 12 years or less to $8.6 \%$ in students aged $\geq 18$ year or more. In secondary-school students (grades $10-12$, ages $15-17$ years), midwakh use ranged from $4.2 \%$ to $5.4 \%$ of students. These rates are substantially lower than those reported by secondary-school students in the United Arab Emirates (24\%) (7). To our knowledge, no other studies have reported the prevalence of midwakh use in middle-school students.

Although the prevalence of midwakh use is still low in Lebanon, dokha use by young adolescents is still concerning, particularly in view of the associations we found with cigarette and waterpipe smoking and parental smoking. Our findings concur with previous evidence on the determinants of smoking in young people (15-17). This situation is of concern because, despite the existence of tobacco control policies at the national level in Lebanon, the overall policy environment in Lebanon - that is, lack of effective enforcement of existing policies (law 174 banning indoor smoking and smoking in public areas) and absence of other regulatory policies (taxation) - is still conducive to tobacco use (18). In addition, government commitment to tobacco product regulation and restrictions on access for young people is lacking, which enables the sale and promotion of tobacco products in this age group.

\begin{tabular}{|c|c|c|c|c|}
\hline Variable & $\begin{array}{l}\text { Students } \\
\text { No. (\%) }\end{array}$ & $\begin{array}{c}\text { Midwakh use } \\
\text { Weighted \% (95\% CI) }\end{array}$ & OR $(95 \%$ CI $)$ & P-value \\
\hline Total & $5590(100)$ & $4.6(3.5-5.9)$ & - & \\
\hline Sex & & & & \\
\hline Male & $2273(40.7)$ & $6.7(5.1-8.8)$ & $1(-)$ & \\
\hline Female & $3309(59.2)$ & $2.7(1.9-3.7)$ & $0.38(0.27-0.53)$ & $<0.001^{*}$ \\
\hline Age (years) & & & & \\
\hline$\leq 12$ & $660(11.8)$ & $2.4(1.4-3.9)$ & $1(-)$ & \\
\hline $13-15$ & $2681(48.0)$ & $4.5(3.2-6.2)$ & $1.91(1.32-2.77)$ & $0.002^{*}$ \\
\hline $16-17$ & $1805(32.3)$ & $5.1(3.6-7.2)$ & $2.21(1.40-3.47)$ & $0.002^{*}$ \\
\hline$\geq 18$ & $428(7.7)$ & $8.6(5.7-12.7)$ & $3.85(2.34-6.32)$ & $<0.001^{*}$ \\
\hline Grade & & & & \\
\hline 7 & $1227(21.9)$ & $5.1(2.9-9)$ & $1(-)$ & \\
\hline 8 & 1099 (19.7) & $4.1(2.9-5.7)$ & $0.79(0.40-1.53)$ & 0.458 \\
\hline 9 & $768(13.7)$ & $3.9(2.9-5.2)$ & $0.75(0.37-1.53)$ & 0.408 \\
\hline 10 & $942(16.9)$ & $4.2(2.7-6.6)$ & $0.81(0.54-1.23)$ & 0.301 \\
\hline 11 & $694(12.4)$ & $4.7(2.5-8.8)$ & $0.92(0.47-1.80)$ & 0.792 \\
\hline 12 & $836(15.0)$ & $5.4(4.1-7.0)$ & $1.05(0.65-1.70)$ & 0.836 \\
\hline Type of sch & & & & \\
\hline Public & $3597(64.3)$ & $6.3(4.1-9.7)$ & $1(-)$ & \\
\hline Private & $1993(35.7)$ & $3.6(2.7-4.7)$ & $0.54(0.31-0.96)$ & $0.037^{*}$ \\
\hline
\end{tabular}

OR: odds ratio; CI confidence intervals.

${ }^{*}$ Statistically significant at $P<0.05$ 


\begin{tabular}{|c|c|c|c|c|c|}
\hline Variable & $\begin{array}{c}\text { Midwakh use } \\
\text { No. (\%) }\end{array}$ & OR (95\% CI) & P-value & ORa $(95 \% \mathrm{CI}) \mathrm{a}$ & P-value \\
\hline \multicolumn{6}{|c|}{$\begin{array}{l}\text { Tried a cigarette before age } 14 \text { years (of those who ever tried } \\
\text { a cigarette) }\end{array}$} \\
\hline No & $39(7.5)$ & $1(-)$ & & $1(-)$ & \\
\hline Yes & $138(15.7)$ & $2.31(1.53-3.49)$ & $0.001^{*}$ & $2.34(1.49-3.68)$ & $0.001^{*}$ \\
\hline \multicolumn{6}{|c|}{ Current cigarette smoker } \\
\hline No & $90(1.6)$ & $1(-)$ & & $1(-)$ & \\
\hline Yes & $161(21.6)$ & $16.61(12.21-22.58)$ & $<0.001^{*}$ & $15.22(11.08-20.90)$ & $<0.001^{*}$ \\
\hline \multicolumn{6}{|c|}{ Waterpipe use } \\
\hline Never & $34(1)$ & $1(-)$ & & $1(-)$ & \\
\hline Ever & $228(9)$ & $9.89(6.78-14.45)$ & $<0.001^{*}$ & $9.61(6.66-13.86)$ & $<0.001^{*}$ \\
\hline \multicolumn{6}{|c|}{ Parent/guardian smokes (any type) } \\
\hline No & $86(3.3)$ & $1(-)$ & & $1(-)$ & \\
\hline Yes & $168(5.2)$ & $1.61(1.13-2.29)$ & $0.011^{*}$ & $1.56(1.05-2.31)$ & $0.029^{*}$ \\
\hline \multicolumn{6}{|c|}{ Exposure to second-hand smoke } \\
\hline No & $59(3.6)$ & $1(-)$ & & $1(-)$ & \\
\hline Yes & $206(4.8)$ & $1.37(0.94-2.0)$ & 0.097 & $1.32(0.91-1.92)$ & 0.128 \\
\hline
\end{tabular}

OR: unadjusted odds ratio; ORa: adjusted odds ratios; $C I$ confidence intervals.

${ }^{a}$ Controlling for age, sex and school type.

*Statistically significant at $P<0.05$.

Exposure of young non-nationals living in the Gulf to midwakh use can help spread this practice globally. More than $15 \%$ of ninth-grade male expatriate students in the United Arab Emirates were current smokers of midwakh and smoked it regularly (25 out of 30 days on average) and often (2-3 times a day) (11). In addition, data from the Global Youth Tobacco Survey on students in grades 10-12 in the United Arab Emirates indicated that about $21 \%$ had ever smoked midwakh, with no difference between national and expatriate students from the USA, Europe or Australia (12). At least two American websites offer access to midwakh products $(19,20)$. The results in this study indicate that midwakh smoking is now present among young people in Lebanon. This situation calls for urgent global attention to prevent midwakh smoking from spreading further among young people and undermining tobacco control efforts.

\section{Limitations}

Only one question was asked on midwakh smoking in the 2017 GSHS in Lebanon, which limits a broader understanding of the pattern of use of this product in students in grades 7-12.

\section{Conclusion}

Global and regional research on midwakh smoking is just beginning. However, as with other tobacco products, understanding the patterns of midwakh use and the development of interventions to reduce its use requires research across different disciplines, such as epidemiology, health promotion, economics, engineering, medicine, chemistry, psychology, policy and others. A recent meeting in the United Arab Emirates - hosted by New York University, Abu Dhabi - brought together researchers on midwakh use and experts on alternative tobacco products used in the Arab region to draft a research agenda (21). We urge relevant regional and global organizations with an interest in reducing tobacco use (excluding the tobacco industry and foundations financed by the tobacco industry) to support research on midwakh before it becomes the next global tobacco pandemic(22,23).

\section{Acknowledgements}

The authors thank the participating schools and students for taking part in the GSHS.

Funding: This work was partially supported by the World Health Organization, Country Office Lebanon, the Centers for Disease Control and Prevention, USA, and the Government of Japan.

Competing interests: None declared. 


\section{Bases factuelles tirées de l'Enquête mondiale en milieu scolaire sur la santé des élèves au Liban sur le tabagisme par midwakh : signe avant-coureur de la prochaine pandémie mondiale de tabagisme? \\ Résumé}

Contexte : Le tabagisme par cigarettes est le premier mode de consommation du tabac, mais d'autres méthodes ont gagné en popularité. Aux Émirats arabes unis ainsi que dans d'autres pays du Golfe, il est courant de consommer la dokha, un type de tabac mélangé à des herbes et des épices, au moyen d'une pipe appelée « midwakh ».

Objectifs : La présente étude avait pour objectif de déterminer la prévalence de l'utilisation de la midwakh parmi les élèves libanais ainsi que les facteurs qui y sont associés.

Méthodes : Les données sur le tabagisme issues de l'Enquête mondiale en milieu scolaire sur la santé des élèves au Liban en 2017 ont été analysées, y compris l'utilisation de la midwakh au moment de l'enquête (définie comme l'utilisation de cette dernière au moins une fois dans les 30 jours ayant précédé l'enquête). L'enquête incluait des collégiens et des lycéens (âge compris entre 12 et 18 ans). En réalisant des analyses bivariées et de régression logistique, nous avons analysé l'utilisation de la midwakh au moment de l'étude en fonction des variables sociodémographiques et liés au tabagisme.

Résultats : Sur les 5590 élèves inclus dans l'analyse, 4,6\% étaient des utilisateurs de la midwakh au moment de l'étude. L'utilisation de la midwakh était significativement plus fréquente chez les élèves de 13 ans et plus et chez les élèves de sexe masculin $(p<0,01)$. L'utilisation de la pipe était statistiquement plus répandue, de façon significative, chez les élèves des écoles publiques par rapport à ceux des écoles privées. Le tabagisme par cigarettes (odds ratio $(\mathrm{OR})=15,22$; intervalle de confiance à $95 \%$ (IC) : 11,08-20,90), le fait d'avoir déjà fumé le narguilé (OR =9,61; IC à 95\%:6,66-13,86) et le tabagisme des parents $(\mathrm{OR}=1,56$; IC à $95 \%: 1,05-2,31)$ étaient également fortement liés à l'utilisation de la midwakh au moment de l'étude.

Conclusion : Bien que l'utilisation de la midwakh soit peu répandue au Liban, les schémas d'association de son utilisation sont analogues à ceux du tabagisme par cigarettes et par narguilé chez les jeunes. Des recherches supplémentaires sont nécessaires pour comprendre le contexte de l'utilisation de la midwakh et pour éviter sa propagation.

$$
\begin{aligned}
& \text { تعاطي التبخ باستخدام المدواخ بين طلاب المدارس في لبنان: تحليل البيانات من المسح العالمي لصحة طلاب المدارس } \\
& \text { ريلا عفيفي، مونيشا سر افنان، نورا الصليبي، ريما نقاش، أليسار راضي، سكوت شرمان، ليليان غندور }
\end{aligned}
$$

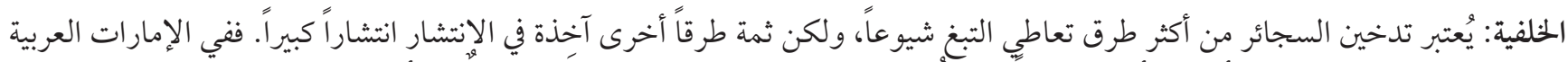

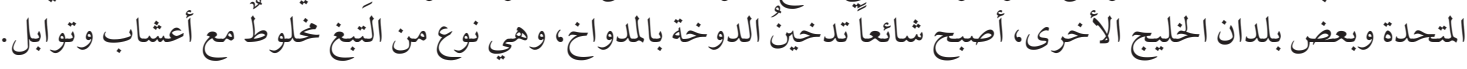
الأهداف: هدفت هذه الدراسة إلى الوقوف على مدى انتشار استخدام المدواخ بين طلاب المدارس في لبنان والعوامل المرتبطة بذلك.

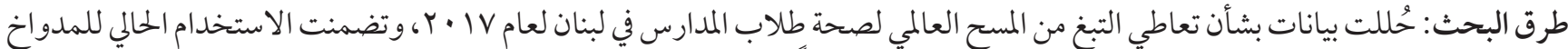

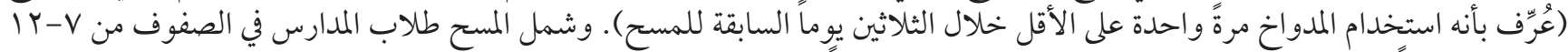

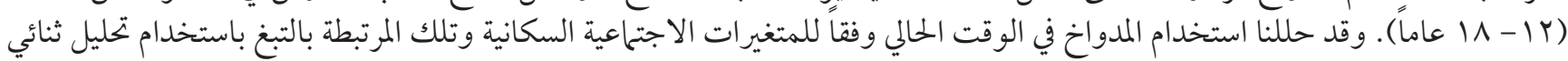
المتغير وتحليل الانحدار اللوجستي.

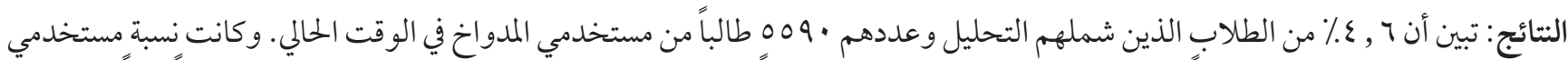

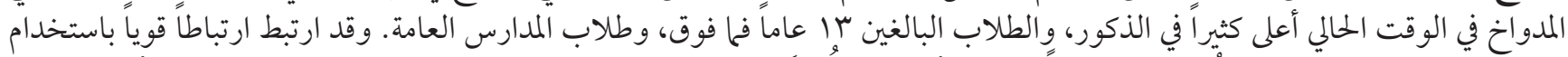

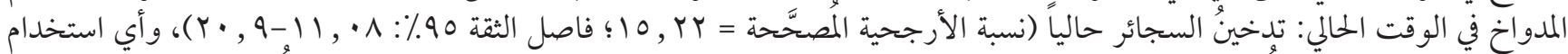

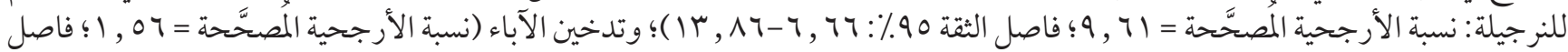
الثقة

الاستنتاج: على الرغم من انخفاض استخدام المدو اخخ في لبنان، إلا أن النحاذج المرتبطة باستخدامه مشابهة لتلك المرتبطة بتدخين السجائر والنرجيلة

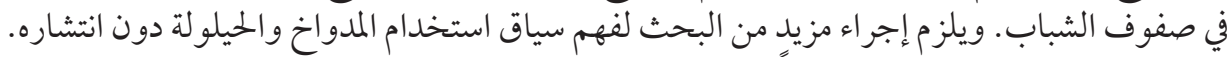




\section{References}

1. WHO Report on the global tobacco epidemic, 2011: warning about the dangers of tobacco. Geneva: World Health Organization; 2011.

2. Drope J, Schluger N, Cahn Z, Drope J, Hamill S, Islami F, Liber A, Nargis N, Stoklosa M. The tobacco atlas. Atlanta: American Cancer Society and Vital Strategies; 2018.

3. Bilano V, Gilmour S, Moffi T, d'Espaignet ET, Stevens GA, Commar A, et al. Global trends and projections for tobacco use, 1990-2025: an analysis of smoking indicators from the WHO Comprehensive Information Systems for Tobacco Control. Lancet. 2015;385 (9972): 966-76. https://doi.org/10.1016/So140-6736(15)60264-1

4. John LJ, Muttappallymyalil J. Dokha: an emerging public health issue as a form of tobacco smoking in the Middle East. Asian Pac J Cancer Prev. 2013;14(12):7065-7. https://doi.org/10.7314/apjcp.2013.14.12.7065

5. Vupputuri S, Hajat C, Al-Houqani M, Osman O, Sreedharan J, Ali R, et al. Midwakh/dokha tobacco use in the Middle East: much to learn. Tob Control. 2016;25(2):236-41. https://doi.org/10.1136/tobaccocontrol-2013-051530

6. Shaikh RB, Muttappallymyalil J, Sreedharan J, Osman OT. A call to address dokha smoking: an emerging form of tobacco use. Public Health. 2014;128(8):766-7. https://doi.org/10.1016/j.puhe.2014.05.01

7. Al Shemmari NA, Shaikh RB, Sreedharan J. Prevalence of dokha use among secondary school students in Ajman, United Arab Emirates. Asian Pac J Cancer Prev. 2015;16(2):427-30. https://doi.org/10.7314/apjcp.2015.16.2.427

8. Shaikh RB, Haque NMA, Al Mohsen HAHK, Al Mohsen AAHK, Humadi MHK, Al Mubarak ZZ, et al. Acute effects of dokha smoking on the cardiovascular and respiratory systems among UAE male university students. Asian Pac J Cancer Prev. 2012;13(5):181922. https://doi.org/10.7314/apjcp.2012.13.5.1819

9. Shaikh RB, Sreedharan J, Al Sharbatti S, Muttappallymyalil J, Lee L, Weitzman M. Salivary cotinine concentration and carbon monoxide levels in young adults smoking midwakh in comparison with cigarette smokers. Tob Control. 2019;28(2):141-145. https://doi.org/10.1136/tobaccocontrol-2017-054202

10. Jayakumary M, Jayadevan S, Ranade AV, Mathew E. Prevalence and pattern of dokha use among medical and allied health students in Ajman, United Arab Emirates. Asian Pac J Cancer Prev. 2010;11(6):1547-9.

11. Asfour LW, Stanley ZD, Weitzman M, Sherman SE. Uncovering risky behaviors of expatriate teenagers in the United Arab Emirates: a survey of tobacco use, nutrition and physical activity habits. BMC Public Health. 2015;15(1):944. doi: https://doi.org/10.1186/ S12889-015-2261-9

12. Jawad M, Al-Houqani M, Ali R, El Sayed Y, ElShahawy O, Weitzman M, et al. Prevalence, attitudes, behaviours and policy evaluation of midwakh smoking among young people in the United Arab Emirates: cross-sectional analysis of the Global Youth Tobacco Survey. PLoS One. 2019;14(4):e0215899. https://doi.org/10.1371/journal.pone.0215899

13. Al-Houqani M, Ali R, Hajat C. Tobacco smoking using midwakh is an emerging health problem - evidence from a large cross-sectional survey in the United Arab Emirates. PLoS One. 2012;7(6). https://doi.org/10.1371/journal.pone.0039189

14. Noncommunicable diseases and their risk factor. Global school-based student health survey (GSHS) [webpage]. World Health Organization (https://www.who.int/ncds/surveillance/gshs/en/, accessed 18 November 2019).

15. Akl EA, Ward KD, Bteddini D, Khaliel R, Alexander AC, Lotfi T, et al. The allure of the waterpipe: a narrative review of factors affecting the epidemic rise in waterpipe smoking among young persons globally. Tob Control. 2015;24(Suppl 1):i13-i21. https:// doi.org/10.1136/tobaccocontrol-2014-051906

16. Leonardi-Bee J, Jere ML, Britton J. Exposure to parental and sibling smoking and the risk of smoking uptake in childhood and adolescence: a systematic review and meta-analysis. Thorax. 2011;66(10):847-55. https://doi.org/10.1136/thx.2010.153379

17. Tyas SL, Pederson LL. Psychosocial factors related to adolescent smoking: a critical review of the literature. Tob Control. 1998;7(4):409-20. https://doi.org/10.1136/tc.7.4.409

18. Nakkash RT, Torossian L, El Hajj T, Khalil J, Afifi RA. The passage of tobacco control law 174 in Lebanon: reflections on the problem, policies and politics. Health Policy Plan. 2018;33(5):633-44. https://doi.org/10.1093/heapol/czyo23

19. Dokha.com. 2017 [website] (https://www.dokha.com/contact.html, accessed 5 October 2019).

20. Hookah-Shisha.com. 2018 [website] (https://www.hookah-shisha.com/store/pc/contact.asp, accessed 5 October 2019).

21. NYU Abu Dhabi Institute. Dokha Tobacco International Symposium. Abu Dhabi, 5-6 November, 2017.

22. Maziak W. Rise of waterpipe smoking. BMJ. 2015;350:h1991. https://doi.org/10.1136/bmj.h1991

23. Ward KD. The waterpipe: an emerging global epidemic in need of action. Tob Control. 2015;24(Suppl 1):i1-i2. https://doi. org/10.1136/tobaccocontrol-2014-052203 